\title{
Growth of Fertilized Maize via Fertirrigation and Foundation With Treated Human Urine and Cassava Wastewater
}

\author{
Jailton G. Ramos ${ }^{1}$, Vera Lucia A. de Lima ${ }^{1}$, Eliton S. G. Sales ${ }^{1}$, Gibran O. de Medeiros ${ }^{1}$, Mariana de O. Pereira ${ }^{1}$, \\ Rafaela F. B. Guimarães ${ }^{1}$, Vitória E. Borges ${ }^{1}$, Thiago G. Sobrinho ${ }^{1}$ \& Géssica G. Ramos ${ }^{2}$ \\ ${ }^{1}$ School of Agricultural Engineering, Universidade Federal de Campina Grande, Campina Grande, PB, Brazil \\ ${ }^{2}$ Center of Science and Technology, State University of Paraíba, Campina Grande, PB, Brazil \\ Correspondence: Jailton G. Ramos, School of Agricultural Engineering, Universidade Federal de Campina \\ Grande, PB, Brazil. Tel: 55-83-988-305-068. E-mail: jailtonbiossistemas@gmail.com
}

Received: January 1, 2018

doi:10.5539/jas.v10n5p188

\author{
Accepted: March 15, 2018 Online Published: April 15, 2018 \\ URL: https://doi.org/10.5539/jas.v10n5p188
}

\begin{abstract}
The agricultural reuse of wastewater is already a reality in several countries of the world. The objective of this work was to evaluate the growth of hybrid corn AG 1051 grown in fertilized soil via the foundation and fertirrigation with the combination of human urine and treated cassava and NPK in protected environment.The experiment was conducted at the Federal University of Campina Grande, Campina Grande, Paraíba. The experimental design was the completely randomized one with 14 treatments and four replications, being two experiments, one fertilized via foundation and the other via fertigation. The treatments were as follows: T1 (NPK), T2 $(470 \mathrm{~mL})$, T3 $(670 \mathrm{~mL}), \mathrm{T} 4(870 \mathrm{~mL}), \mathrm{T} 5(1070 \mathrm{~mL}), \mathrm{T} 6(1270 \mathrm{~mL}), \mathrm{T} 7(1470 \mathrm{~mL})$ applied via fertilization of fertirrigado, and the same dosages applied via fertirrigation corresponding to T9 mineral fertilization, and T10, T11, T13 and T14 the different doses of organic fertilization. There was an average increase of $17.32 \%$ in the Index of Emergency Speed for the seeds that were cultivated in soil fertilized with T3 and T4 in relation to the one fertilized with NPK (T1), the soil fertilized with T3 was the one that presented the highest \%E (Emergency Percentage) with 98, 81\%. At 15 days after the emergency (DAE), the chemical fertilization through the foundation promoted greater leaf area gain differently than at 65 DAE. The organic fertilization via fertigation promoted the highest gains for absolute and relative growth rates of plant height stem diameter and number of leaves.
\end{abstract}

Keywords: agricultural reuse, wastewater, yellow water, Zea Mays L.

\section{Introduction}

Technological advances, the need for speed of agricultural production systems facing the large global food demand, after all, respond to an estimated population of 7 billion people who need to be fed. In the last decades there has been an increase in the consumption of agricultural inputs, and intrinsic to this is the generation of solid, liquid and gaseous residues from these agro-industrial activities, thus enhancing the various environmental, social and economic impacts generated by them. This way, it has increasingly stimulated studies that seek, besides the treatment, the use of these residues generated by agro-industrial activities (Marques et al., 2017; Kraemer, 2014).

In this context, there are large demands for the use of wastewater from domestic sewage, industry and starch factories, which is produced daily. With evidence and national and international discussions about water use conflicts and the fact that water consumption for irrigation is significant, in Brazil it is equivalent to $63 \%$ of the total volume (ANA, 2002). The interest in the use of sanitary sewage and agro-industrial residual water in substitution, although complementary to the sources normally used for irrigation, has increased.

Throughout the world, there is a need to study and discover sustainable technologies with a focus on bioenergy, through which they have been the focus of several studies about their applicability. Among these sustainable technologies is the agricultural reuse of cassava wastewater and human urine or yellow water. Aggregation of value to agro-industrial and sanitary waste can contribute to a more sustainable social and economic development. Therefore, the reuse of yellow water and cassava wastewater in agriculture should be seen as a viable alternative for recycling these residues as a source of nutrients for the plants, thus mitigating the 
environmental impacts generated by the inadequate disposal of these effluents in the environment (Dantas et al., 2015).

Maize (Zea Mays L.) cultivation plays a major socioeconomic role due to its great agricultural aptitude and its various ways of processing it in the high technology industry, whether for human or animal feeding, spreading its acceptance and added value in the market. Brazil is among the world's three largest producers of grain, only behind the United States and China (Embrapa Milho e Sorgo, 2012; Picarelli, 2012). Fertilization is the main factor that can jeopardize the production of maize, and can thus also influence the quality of the grains. It is important to note that the most important and demanded macronutrient for this crop is nitrogen, followed by potassium and phosphorus, which presents higher responses in terms of productivity (Duarte et al., 2003).

Human urine is a liquid waste that is eliminated by the human body, secreted by the kidneys through a process of blood filtration called urination and excreted through the urethra (Karak \& Bhattacharyya, 2011). This biofertilizer is rich in nitrogen and from all human excreta, it contains about $90 \%$ of nitrogen, which $80 \%$ is in the form of urea while the rest is in the form of organic and inorganic nitrogen (Fittschen \& Hahn, 1998).

A concern about the use of human urine with biofertilizer is about the sanitary issues of the same, for the possible presence of pathogenic microorganisms, as well as the concentration of sodium chloride $(\mathrm{NaCl})$. Therefore, urine after being submitted to the process of anaerobic digestion rises its $\mathrm{pH}$ to alkaline around 9.0, so these pathogenic microorganisms cannot develop, and as far as sodium chloride, according to Ganrot et al. 2007, human urine contains about $150 \mathrm{mM} \mathrm{NaCl}$, corresponding to a concentration of 8.8 grams per liter.

The cassava wastewater is a liquid residue of milky aspect and strong odor generated in the process of processing cassava (Manihot esculeta Crantz) for the production of flour or starch, with high concentrations of nutrients, mainly potassium; it also has sugars, starches, proteins, linamarin, salts and other substances (Duarte et al., 2012). Among all the residues generated in the processing of manihot, periderm, maniva, mahogany, smoke, noise, grease and heat, cassava wastewater presents the highest pollutant potential due to its high organic load and the presence of high concentrations of linamarine glycosides (93\%) and lotaustraline (7\%) in a lower concentration, which are high toxicity cyanogenic glycosides with high BOD, causing eutrophication of water bodies, death of aquatic fauna and intoxication, even leading to the death of animals that may consume it in high amounts. These glycosides combine with hemoglobin in the blood, acting as inhibitors of the respiratory chain (Do Nascimento et al., 2013, Cereda, 2003).

In this context, the objective of the present work is to evaluate the growth of hybrid corn AG 1051 grown in fertilized soil via fertilization of fertilizer and fertirrigado with the combination of treated human urine, cassava wastewater and NPK in protected environment.

\section{Method}

The study was developed at the Federal University of Campina Grande, campus I, Campina Grande, Paraíba whose central geographic coordinates are $7^{\circ} 13^{\prime} 51^{\prime \prime} \mathrm{S}$ and $35^{\circ} 52^{\prime} 54^{\prime \prime} \mathrm{W}, 512$ meters above sea level in the year 2017 in a plastic greenhouse with 32 meters long and 20 wide, an area of $640 \mathrm{~m}^{2}$, metallic structure, being of the type roof and arch, covered with low density polyethylene of $150 \mu \mathrm{m}$ and sides covered with shading screen with $80 \%$ protection index.

Monitoring of maximum and minimum temperature was carried out in the greenhouse during all stages of development of the crop. The readings were always performed daily at 9:00 am with the aid of a digital thermometer (Figure 1). 


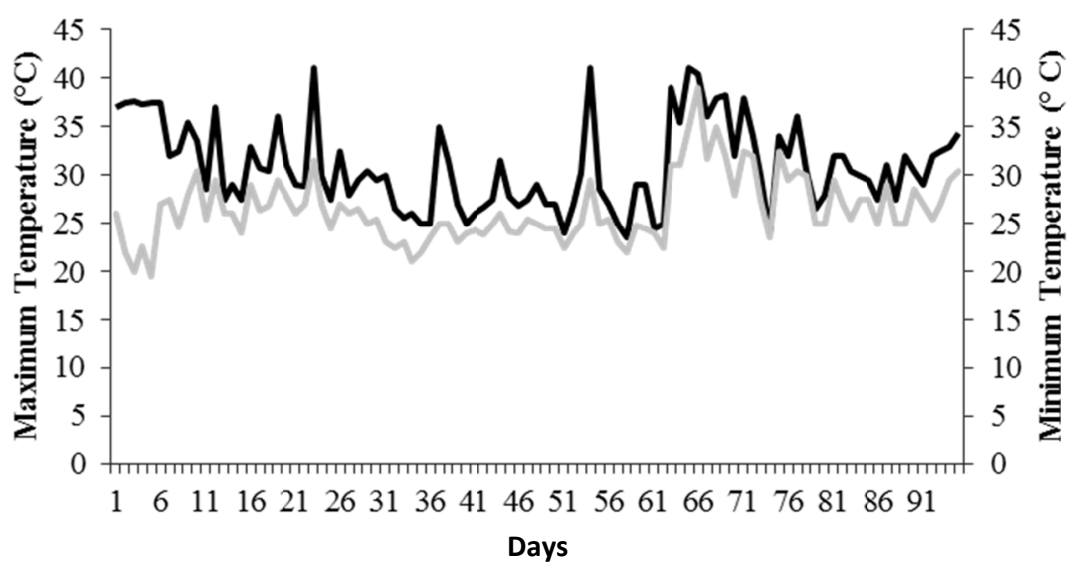

Maximum Temperature $\left({ }^{\circ} \mathrm{C}\right) \quad$ Minimum Temperature $\left({ }^{\circ} \mathrm{C}\right)$

Figure 1. Values of the maximum temperature $\left({ }^{\circ} \mathrm{C}\right)$ and minimum temperature $\left({ }^{\circ} \mathrm{C}\right)$ inside the greenhouse

The choice of cultivating hybrid corn AG 1051 used in the study was due to its cultivation and its great acceptance by the farmers, mainly familiar ones, since it has the potential of production for fresh, dry and/or processed commercialization, thus benefiting even presents large amounts of straw that is used for silage manufacture, used in animal feed.

The soil used in the experiment was classified as Etrophic Litrophic (Embrapa, 2006) with the following physicochemical characteristics: $\mathrm{pH}$ in water $(1: 2: 5)=5.58 ; \mathrm{CE}=0.56 \mathrm{mmhos} \mathrm{cm}^{-1} ; \mathrm{Al}=0.00 \mathrm{cmol}_{\mathrm{c}} \mathrm{dm}^{-3} ; \mathrm{Mg}=$ $2.78 \mathrm{cmol}_{\mathrm{c}} \mathrm{dm}^{-3} ; \mathrm{Ca}=9.07 \mathrm{cmol}_{\mathrm{c}} \mathrm{dm}^{-3} ; \mathrm{K}=0.33 \mathrm{cmol}_{\mathrm{c}} \mathrm{dm}^{-3} ; \mathrm{Na}=1.64 \mathrm{cmol}_{\mathrm{c}} \mathrm{dm}^{-3} ; \mathrm{P}=3.98 \mathrm{cmol}_{\mathrm{c}} \mathrm{dm}^{-3} ; \mathrm{S}=$ $13.72 \mathrm{cmol}_{\mathrm{c}} \mathrm{dm}^{-3}$; Organic Carbon $=1.70 \%$; Organic matter $=2.93 \%$ and soil density $=1.28 \mathrm{~g} \mathrm{~cm}^{-3}$.

The assembly and spatial distribution of the experimental units occurred by spacing 0.8 and $0.5 \mathrm{~m}$ between columns. A total of 5620 -liter pots were used. At the lower end of each vessel, a 3-mm drill bit was drilled, and a flexible transparent drain was installed to drain the well. Under this hole, made in each vase, it was placed a geotextile blanket, with the purpose to prevent clogging of it. A layer of $0.3 \mathrm{~kg}$ of gravel No. 1 was placed above the geotextile or bidim blanket, and soon thereafter it was placed $33 \mathrm{~kg}$ of soil.

The experimental units were located $0.5 \mathrm{~m}$ from the ground, where, at the lower end, immediately after the drain, 2 liter plastic bottles were coupled with the purpose of recirculating the entire drained volume, thus promoting recirculation of nutrients that might be leached at the irrigation events.

After the organization of the experimental units, these were submitted to the condition of near field capacity, the water used was rainwater with electrical conductivity $\mathrm{CE}=0.04 \mathrm{dS} \mathrm{cm}^{-1}$. As soon as the soil was close to field capacity and there was no more drainage 24 hours after the irrigation event, the treatments were then applied.

The experimental design was completely randomized with four replicates, determined in two experiments. T1 (NPK), T2 $(470 \mathrm{~mL})$, T3 $(670 \mathrm{~mL})$, T4 $(870 \mathrm{~mL})$, T5 $(1070 \mathrm{~mL})$, T6 $(1270 \mathrm{~mL})$, T7 $(1470 \mathrm{~mL})$ applied fetilization of fertirrigado, and experiment 2 via fertirrigation: T8 (F-NPK), T9 (F-470 mL), T10 (F-670 mL), T11 (F-870 mL), T12 (F-1070 mL), T13 (F-1270) and T14 (F-1470), obtaining 14 treatments and totaling 56 experimental units. Eight fertigations were performed at five day intervals between each.

The estimation of the volume of human urine and cassava wastewater applied in each experimental unit was determined according to the methodology of Novais et al. (1991), based on the concentration of nitrogen present in the human urine and the potassium present in the cassava wastewater, due to its high concentrations in each effluent respectively. Chemical fertilization (NPK) was also estimated through the proposed methodology of Novais et al. (1991), whereby the nitrogen source was calcium nitrate $\left(15.5 \% \mathrm{Ca}\left(\mathrm{NO}_{3}\right)_{2}\right)$, phosphorus was simple orthophosphate $\left(18 \% \mathrm{P}_{2} \mathrm{O}_{5}\right)$ and potassium chloride $(60 \% \mathrm{~K})$.

The human urine used as a source of nutrients in the experiment came from three residential urinals of the municipality of Campina Grande, Paraíba where by means of plastic bottles, as soon as human urine was expelled the same was collected and then stored. Before being used, human urine was subjected to a previous treatment, whereby it was stored in a sealed 20-liter plastic drum, where it was allowed to stand for 60 days 
under the action of anaerobic bacteria that digested the effluent by raising the its $\mathrm{pH}$, leaving it with alkaline $\mathrm{pH}$, around 9.0 (Figure 2).

The cassava wastewater used in the experiment was collected from an artisanal starch factory in the municipality of Puxinanã-PB, which was also submitted to an anaerobic digestion process in an airtight, 85-liter plastic container, where there was an air column of $5 \mathrm{~cm}$ between the effluent and its edge. In the lid of the reservoir it was placed a hose with the other end connected to a PET bottle with water at the height of $5 \mathrm{~cm}$ to release the gases generated during the digestion of the effluent, especially hydrocyanic acid, which by the presence of a cyanogenic glycoside known as linamarin, that when hydrolyzed releases large amount of this acid in the effluent.

After the treatments the physical-chemical characterization of the human urine and the cassava wastewater was carried out following the methodology proposed by Standard Methods for Wastewater (APHA, AWWA, \& WEF, 2005) (Table 1).

Table 1. Physical-chemical characterization of treated cassava wastewater and human urine

\begin{tabular}{|c|c|c|c|c|c|c|c|}
\hline \multicolumn{8}{|c|}{ Treated human urine } \\
\hline $\mathrm{pH}$ & $\mathrm{CE}(\mathrm{mS} / \mathrm{cm})$ & DQO $\left(\mathrm{mg} \mathrm{O}_{2} / \mathrm{L}\right)$ & NTK (mg/L) & $\mathrm{PO}_{4}{ }^{3-}(\mathrm{mg} / \mathrm{L})$ & $\mathrm{K}(\mathrm{mg} / \mathrm{L})$ & $\mathrm{Na}(\mathrm{mg} / \mathrm{L})$ & $\mathrm{Ca}+\mathrm{Mg}\left(\mathrm{mg} \mathrm{CaCO}_{3} / \mathrm{L}\right)$ \\
\hline 9.00 & 2.07 & 336.54 & 14994 & 761.37 & 2257.28 & 3310.52 & 2.85 \\
\hline \multicolumn{8}{|c|}{ Treated cassava wastewater } \\
\hline $\mathrm{pH}$ & $\mathrm{CE}(\mathrm{mS} / \mathrm{cm})$ & $\mathrm{DQO}\left(\mathrm{mgO}_{2} / \mathrm{L}\right)$ & NTK (mg/L) & $\mathrm{PO}_{4}{ }^{3-}(\mathrm{mg} / \mathrm{L})$ & $\mathrm{K}(\mathrm{mg} / \mathrm{L})$ & $\mathrm{Na}(\mathrm{mg} / \mathrm{L})$ & $\mathrm{Ca}+\mathrm{Mg}\left(\mathrm{mg} \mathrm{CaCO}_{3} / \mathrm{L}\right)$ \\
\hline 3.05 & 10.68 & 69230.76 & 945.50 & 218.26 & 3307.47 & 272.95 & 19.95 \\
\hline \multicolumn{8}{|c|}{ Solution (Human urine + treated cassava wastewater) } \\
\hline $\mathrm{pH}$ & $\mathrm{CE}(\mathrm{mS} / \mathrm{cm})$ & $\mathrm{DQO}\left(\mathrm{mgO}_{2} / \mathrm{L}\right)$ & NTK (mg/L) & $\mathrm{PO}_{4}^{3-}(\mathrm{mg} / \mathrm{L})$ & $\mathrm{K}(\mathrm{mg} / \mathrm{L})$ & $\mathrm{Na}(\mathrm{mg} / \mathrm{L})$ & $\mathrm{Ca}+\mathrm{Mg}\left(\mathrm{mg} \mathrm{CaCO}_{3} / \mathrm{L}\right)$ \\
\hline 7.15 & 38.08 & 46246.15 & 9878.40 & 438.20 & 2730.15 & 2010.15 & 11.21 \\
\hline
\end{tabular}

Note. pH: Hydrogenionic Potential; EC: Electrical Conductivity; COD: Chemical Oxygen Demand; NTK: Total Kjeldahl Nitrogen; $\mathrm{PO}_{4}{ }^{3-}$ : Orthophosphate; K: Potassium; Na: Sodium and $\mathrm{Ca}+\mathrm{Mg}$ : Total Hardness.

In order to try to reduce the $\mathrm{pH}$ of the solution, some simulations were performed, varying the volume of human urine as a function of the volume of cassava wastewater used. Thus, it was possible to achieve a $\mathrm{pH}$ of 7.15 by preparing the solution with $475 \mathrm{ml}$ of human urine and $500 \mathrm{ml}$ of cassava wastewater.

Foundation fertilization with the combination of human urine and treated cassava wastewater was performed when the soil was close to field capacity, which was maintained for a period of 15 days for the solution to stabilize and interact with the soil. The fertigations were divided into eight sessions, with intervals of five days between each, by means of which the volume of solution applied in T8 (F-NPK) was diluted in $1200 \mathrm{~mL}$ of distilled water, making $150 \mathrm{~mL}$ fertigations per session, T9 (F-470 mL) was $58.75 \mathrm{~mL}$ per session, $\mathrm{T} 10$ (83.75 $\mathrm{mL})$, T11 (108.75 mL), T12 (133.75 mL per session), T13 (158.75) and T14 (183.75 mL per session). Fertigations were initiated only when seedlings had three to four fully expanded leaves. For the NPK solution, the nutrients were diluted in six liters of distilled water, and this was applied following the same methodology as the treated human urine and cassava wastewater solutions.

The irrigation was determined following the principle of drainage lysimetry by methodology submitted by Bernardo et al. (2008). The water used for maize irrigation came from a polyethylene water box of $5 \mathrm{~m}^{3}$ of rain water, which had an EC of $0.04 \mathrm{dS} / \mathrm{cm}$. Throughout the development of the crop there was the presence of carcass caterpillar (Spodoptera frugiperda) and whitefly (Bemisia argentifolii) through which the control was performed manually and with use of Mospilan insecticide respectively.

At 15 days after the foundation fertilization of experiment 1, seven seeds of maize were sown per experimental unit. Daily the quantification of the number of emerged seedlings was carried out to the point that became constant. Thus, it was possible to determine the percentage of emergency $(\% \mathrm{E})$ and the Index of Emergency Speed (IVE), following the methodology given by Maguire (1962),

$$
\% E=\left(\frac{N}{A}\right) \times 100
$$

where,

$\% \mathrm{E}$ : percentage of emergence; $\mathrm{N}$ : total number of seeds emerged; A: total number of seeds sown. 


$$
\mathrm{IVE}=\left(\frac{\mathrm{N} 1}{\mathrm{D} 1}+\frac{\mathrm{N} 2}{\mathrm{D} 2}+\ldots+\frac{\mathrm{Nn}}{\mathrm{Dn}}\right)
$$

where,

IVE: emergency speed index; N: number of seedlings verified on the day of the count, DQ: number of days after sowing at which the counting was performed. It was considered those seedings that managed to break the soil surface.

Analyzes of the effects of treatments under corn growth were performed 15 days after emergence (15 DAE) and at the end of the experiment (65 DAE). The variables evaluated were absolute and relative growth rates of plant height (TCAAP and TCRAP), stem diameter (TCADC and TCRDC), leaf number (TCANF and TCRNF) and leaf area (FA).

The variable (PA) was determined with the help of a diastrometer, measuring from the ground neck to the end of the last leaf. A digital caliper with a precision of $0.05 \mathrm{~mm}$ was used for (DC), always taking as base the lower end of the stem, near the lap of the ground. The variable (NF) was determined by direct counting.

The leaf area (AF, $\mathrm{cm}^{2}$ plant $^{-1}$ ) was estimated according to a method proposed by Francis et al. (1969), which relates the largest leaf width (B) and the average leaf length (L) of the corn plant. This estimation was performed through the equation:

$$
\mathrm{AF}=(0.75 * \mathrm{~L} * \mathrm{~B})
$$

where,

AF: leaf area of the plant, B: maximum width of each leaflet and L: main vein length, and 0.75 a correction constant.

Based on the data, the absolute and relative growth rates for plant height and collection diameter (Eq. 4 and Eq. 5) were determined (Benincasa, 2003).

$$
\begin{gathered}
\mathrm{TCR}=\left(\frac{\ln \mathrm{B} 2-\ln \mathrm{B} 1}{\mathrm{t} 2-\mathrm{t} 1}\right) \\
\mathrm{TCA}=\left(\frac{\mathrm{B} 2-\mathrm{B} 1}{\mathrm{t} 2-\mathrm{t} 1}\right)
\end{gathered}
$$

where,

TAC $=$ absolute growth rate of plant height, stem diameter and number of leaves $\left(\mathrm{cm}^{-1}\right.$ and mm-day $\left.{ }^{-1}\right) ; \mathrm{TCR}^{-1}=$ relative growth rate for plant height and stem diameter, respectively $\left(\mathrm{cm}^{-1}\right.$ and $\left.\mathrm{mm}-\mathrm{day}^{-1}\right)$; A1 and A2 = foliar areas of two consecutive samplings $\left(\mathrm{cm}^{2}\right) ; \mathrm{B} 1=$ time growth variable $\mathrm{t} 1(\mathrm{~cm}, \mathrm{~mm}) ; \mathrm{B} 2=$ time growth variable $\mathrm{t} 2$ $(\mathrm{cm}, \mathrm{mm})$; All data were submitted to analysis of variance by the $\mathrm{F}$ test, and in the case where significance was observed $(\mathrm{p}<0.05)$, a Tukey averages comparison test was performed with the statistical software SISVAR-ESAL (Ferreira, 2011).

\section{Results and Discussion}

The foundation fertilizations promoted statistically significant differences between the solution doses indicating that the applied solution doses had an influence on IVE and \%E. The treatments that promoted the highest IVE were T3 and T7, and there were no statistically significant differences between them. The use of NPK did not favor higher values for this variable, even though the nutrient concentrations recommended for the development of the potted crop were applied to the soil. Thus, there was an average increase of $17.32 \%$ in the rate of emergence for the seeds that were cultivated in the soil fertilized with T3 and T4 in relation to the fertilized with NPK (T1), the soil fertilization with $1270 \mathrm{~mL}$ of solution was which generated the lowest IVE in relation to the other treatments (Figure 2).

There were statistical differences for variable percentage of emergence $(\% \mathrm{E})$ according to the different types of fertilization of foundation (mineral and organic). Therefore, fertilization with T3 was the one that presented the highest $\% \mathrm{E}$ with $98.81 \%$ different from when the soil was fertilized only with NPK that presented a $(\% \mathrm{E})$ of $80.95 \%$ with a percentage difference of $18.12 \%$ between these (Figure 3 ). 


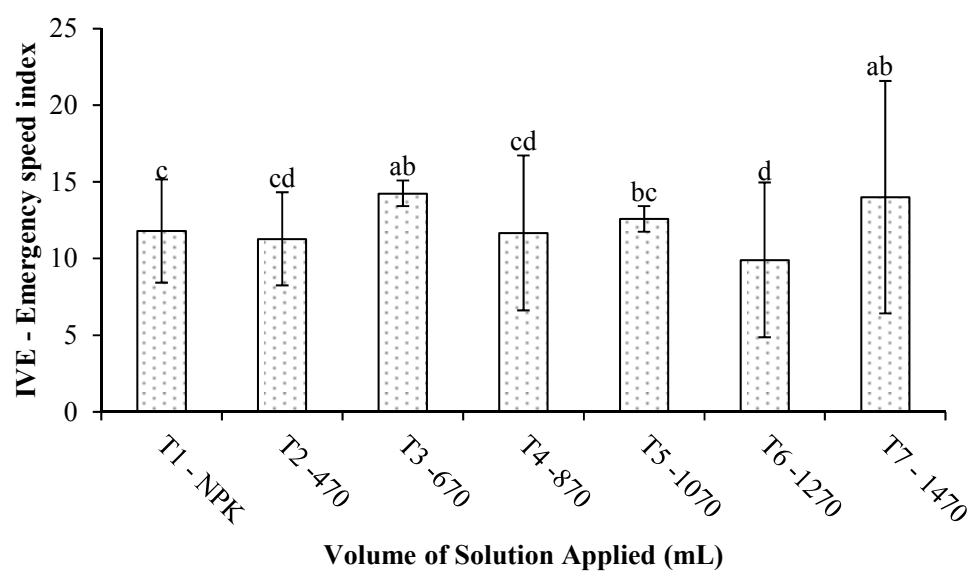

Figure 2. Emergency speed index (IVE) as a function of mineral fertilization and increasing doses of solution (human urine + treated cassava wastewater)

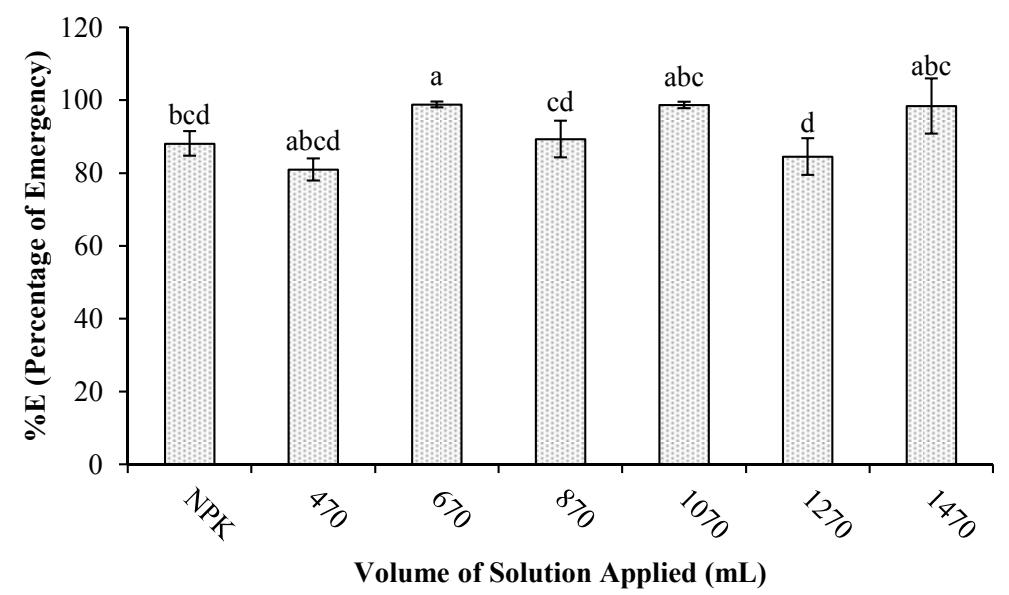

Figure 3. Percentage of Emergency $(\% \mathrm{E})$ as a function of mineral fertilization and increasing doses of solution (human urine + treated cassava wastewater)

The application of increasing doses of solution did not promote linear reduction for IVE and \%E variables. According to Barreto et al. (2014), in a study to evaluate the vegetative development of maize submitted to increasing doses of cassava, it was observed that the increase of the doses of cassava resulted in a significant linear decrease in the height of the maize plants. However, this effect may have been caused by the storage time of cassava, thus favoring a longer period of aerobic digestion, as well as the volatilization of the hydrocyanic acid contained therein, as well as the mixture with the treated human urine, which with alkaline $\mathrm{pH}$ accentuated the $\mathrm{pH}$ of the solution the range of 7.15 , or close to neutrality.

Regarding the leaf area in stage V4, at 15 DAE (with four leaves fully expanded), at which time fertigations were initiated and at 65 in the R3 stage (milky grain formation). Significant treatment effects were observed at 15 and 65 DAE. At 15 DAE the treatment that favored the production of a larger leaf area was the NPK fertirrigation, in contrast T1 (NPK) applied with fertilization of the foundation was the one that promoted the lowest leaf area gain among all the other treatments, with a percentage difference of $59.36 \%$ over T8. No statistical differences were observed between T5, T9 and T11 with an average leaf area of $125.74 \mathrm{~cm}^{2}$ plant $^{-1}$. What could have promoted this increase in leaf area of maize when fertirrigado with NPK was the way in which it was applied to the soil for absorption and consequent absorption of nutrients in a diluted way, thus facilitating the use of these nutrients by plants, since it received eight fractions of nutrient solution of NPK (Figure 4A). According to Basi et al. (2011) Nitrogen is the main primary macronutrient determinant for plant growth, development and yield since it can influence the physiological processes essential for plant life maintenance. 
At 65 DAE there were also statistical differences between the treatments for FA, however, unlike FA at 15 DAE, for this variable the differences were not very different from each other. The treatments that promoted the greatest increases of leaf area were T3, T6 and T8 (Figure 4B). Regarding T8, the same effect was observed for this variable at $15 \mathrm{DAE}$, indicating that the fertirrigation with NPK promoted the highest increases of AF both at 15 and 65 DAE. Fertilization with T2 and T13 yielded the lowest leaf area gains, 375.0 and $356.66 \mathrm{~cm}^{2} \mathrm{plant}^{-1}$, respectively, with a mean percentage difference of $34.88 \%$ in relation to $\mathrm{T} 3$, $\mathrm{T} 6$ and $\mathrm{T} 8$.
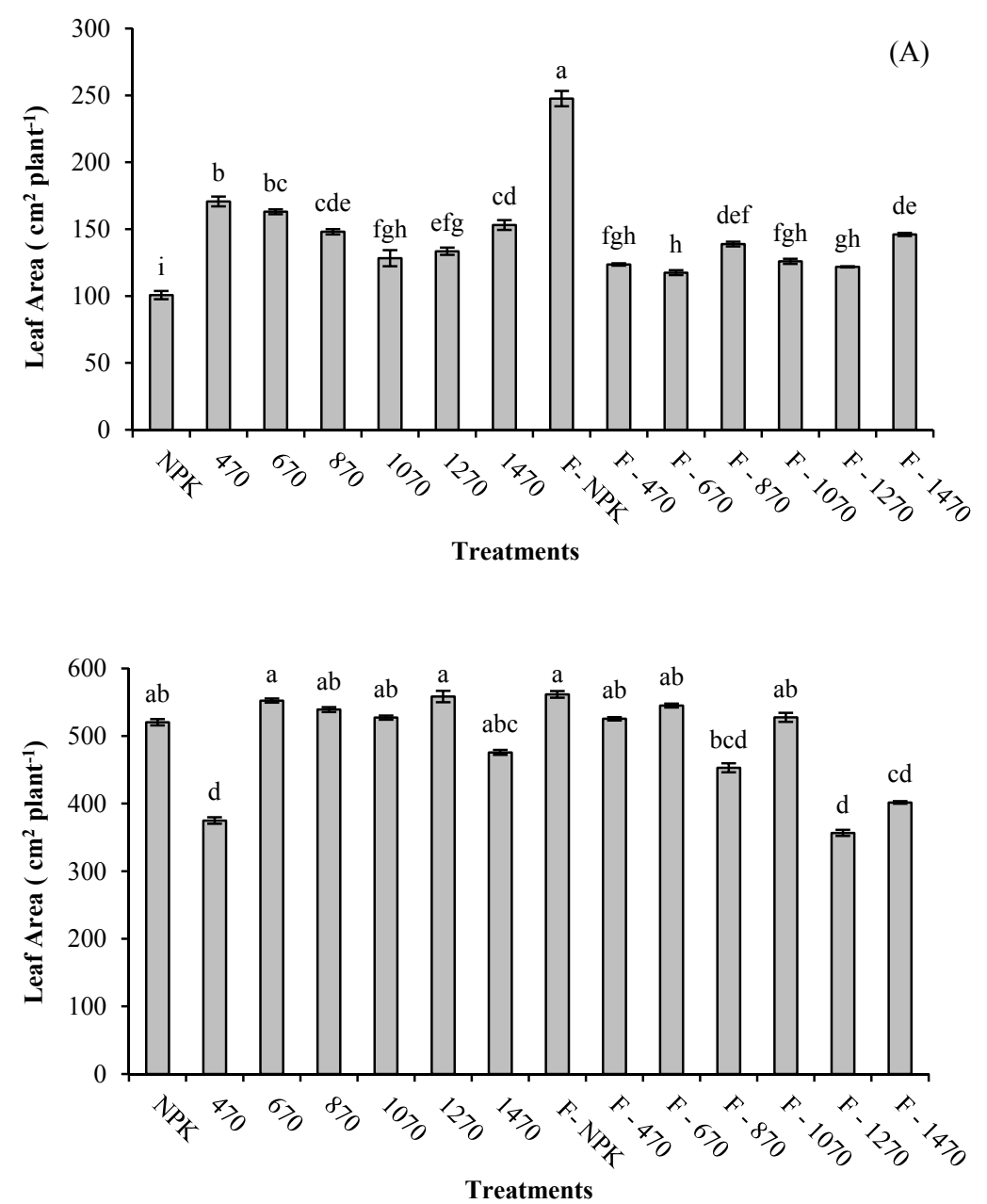

Figure 4. Leaf area $\left(\mathrm{cm}^{2}\right.$ plant $\left.{ }^{-1}\right)$ of maize cultivated in protected environment and in fertilized soil organic and mineral fertilization via fertilization of foundation and fertirrigation

In relation to the fertilization form, the fertilization of the foundation showed the highest leaf area gains in relation to fertilization via fertigation at 15 DAE and 65 DAE, with the exception of fertirrigation with NPK (T8). 
Table 3. Summary of the analysis of variance for absolute and relative growth rate of plant height, coleto diameter and number of leaves of maize fertilized with treated human urine and cassava wastewater

\begin{tabular}{|c|c|c|c|c|c|c|}
\hline FV & $\begin{array}{l}\mathrm{TCA}_{\mathrm{AP}} \\
\left(\mathrm{cmdia}^{-1}\right)\end{array}$ & $\begin{array}{l}\mathrm{TCA}_{\mathrm{DC}} \\
\left(\mathrm{mmdia}^{-1}\right)\end{array}$ & $\mathrm{TCA}_{\mathrm{NF}}$ & $\begin{array}{l}\mathrm{TCR}_{\mathrm{AP}} \\
\left(\mathrm{cmdia}^{-1}\right)\end{array}$ & $\begin{array}{l}\mathrm{TCR}_{\mathrm{DC}} \\
\left(\mathrm{mmdia}^{-1}\right)\end{array}$ & $\mathrm{TCR}_{\mathrm{NF}}$ \\
\hline T1-NPK & 3.26 bcde & $0.17 \mathrm{ab}$ & $0.110 \mathrm{ab}$ & $0.032 \mathrm{~b}$ & $0.719 \mathrm{ab}$ & $0.715 \mathrm{ab}$ \\
\hline $\mathrm{T} 2-470 \mathrm{~mL}$ & 2.94 cde & $0.045 \mathrm{ef}$ & $0.040 \mathrm{~b}$ & $0.037 \mathrm{ab}$ & $0.707 \mathrm{e}$ & $0.710 \mathrm{~b}$ \\
\hline $\mathrm{T} 3-670 \mathrm{~mL}$ & $3.36 \mathrm{bcd}$ & $0.037 \mathrm{ef}$ & $0.102 \mathrm{ab}$ & $0.037 \mathrm{ab}$ & $0.708 \mathrm{de}$ & $0.712 b$ \\
\hline $\mathrm{T} 4-870 \mathrm{~mL}$ & $2.81 \mathrm{de}$ & 0.107 bcde & $0.102 \mathrm{ab}$ & $0.032 \mathrm{~b}$ & 0.712 cde & $0.714 \mathrm{ab}$ \\
\hline $\mathrm{T} 5-1070 \mathrm{~mL}$ & $3.18 \mathrm{bcde}$ & $0.021 \mathrm{f}$ & $0.122 \mathrm{ab}$ & $0.040 \mathrm{ab}$ & $0.707 \mathrm{e}$ & $0.714 \mathrm{ab}$ \\
\hline T6-1270 mL & $3.32 \mathrm{bcd}$ & $0.167 \mathrm{abc}$ & $0.085 \mathrm{ab}$ & $0.040 \mathrm{ab}$ & $0.714 \mathrm{bcd}$ & $0.714 \mathrm{ab}$ \\
\hline $\mathrm{T} 7-1470 \mathrm{~mL}$ & $2.67 \mathrm{e}$ & $0.060 \mathrm{ef}$ & $0.137 \mathrm{a}$ & $0.033 \mathrm{~b}$ & $0.710 \mathrm{cde}$ & $0.715 \mathrm{ab}$ \\
\hline T8-F NPK & 3.08 bcde & $0.080 \mathrm{def}$ & $0.115 \mathrm{ab}$ & $0.033 \mathrm{~b}$ & 0.710 cde & $0.714 \mathrm{ab}$ \\
\hline T9-F $470 \mathrm{~mL}$ & 2.92 cde & $0.158 \mathrm{abcd}$ & $0.100 \mathrm{ab}$ & $0.040 \mathrm{ab}$ & $0.715 a b c$ & $0.715 \mathrm{ab}$ \\
\hline T10-F $670 \mathrm{~mL}$ & $3.59 \mathrm{ab}$ & $0.208 \mathrm{a}$ & $0.155 \mathrm{a}$ & $0.045 \mathrm{a}$ & $0.721 \mathrm{a}$ & $0.717 \mathrm{ab}$ \\
\hline T11-F $870 \mathrm{~mL}$ & 3.12 bcde & $0.180 \mathrm{ab}$ & $0.122 \mathrm{ab}$ & $0.040 \mathrm{ab}$ & $0.721 \mathrm{a}$ & $0.715 \mathrm{ab}$ \\
\hline T12-F $1070 \mathrm{~mL}$ & $4.04 \mathrm{a}$ & 0.111 bcde & $0.160 \mathrm{a}$ & $0.047 \mathrm{a}$ & $0.714 \mathrm{bcd}$ & $0.717 \mathrm{ab}$ \\
\hline T13-F $1270 \mathrm{~mL}$ & $3.46 \mathrm{abc}$ & $0.099 \mathrm{cdef}$ & $0.147 \mathrm{a}$ & $0.042 \mathrm{ab}$ & $0.714 \mathrm{bcd}$ & $0.715 \mathrm{ab}$ \\
\hline T14-F $1470 \mathrm{~mL}$ & $2.92 \mathrm{cde}$ & $0.090 \mathrm{cdef}$ & $0.170 \mathrm{a}$ & $0.040 \mathrm{ab}$ & 0.712 cde & $0.721 \mathrm{a}$ \\
\hline Residue & 0.057548 & 0.001172 & 0.000563 & 0.000017 & 0.000007 & 0.000011 \\
\hline $\mathrm{CV} \%$ & 7.51 & 31.01 & 3.02 & 10.58 & 0.36 & 0.46 \\
\hline DMS & 0.603 & 0.086 & 0.059 & 0.010 & 0.006 & 0.008 \\
\hline
\end{tabular}

Note. * Significant at 5\%; CV\%: coefficient of variation; DMS: minimum significant difference. The variables $\mathrm{TCA}_{\mathrm{NF}}, \mathrm{TCR}_{\mathrm{DC}}$ and $\mathrm{TCR}_{\mathrm{NF}}$ were transformed using the equation $(\mathrm{X}+0.5)^{0.5}$.

About the summary of the analysis of variance all the relative and absolute growth rates in the period of 15-65 DAE were significant at a 5\% probability level by the Tukey averages comparison test, with the exception of the TCRFN. The TCADC was the variable that presented the highest coefficient of variation, evidencing the dispersion of the data.

There was a lot of variation between the effects of the treatments for $\mathrm{TCA}_{\mathrm{AP}}, \mathrm{TCA}_{\mathrm{DC}}$ and $\mathrm{TCR}_{\mathrm{DC}}$. For absolute growth rate of plant height, the treatment that promoted the greatest increases was when the soil was fertilized with $1070 \mathrm{~mL}$ of solution (T12), followed by T10 that presented a gain of $3.59 \mathrm{~cm} \mathrm{day}^{-1}$, the treatment that promoted the lowest gain was T7 (fertilization of the foundation with the maximum dosage of solution with 1470 $\mathrm{mL}$ ), thus presenting a percentage difference of $33.91 \%$ in relation to $\mathrm{T} 12$. For $\mathrm{TCA}_{\mathrm{DC}}$ as for $\mathrm{TCA}_{\mathrm{AP}}$ there were many significant statistical differences between treatments, however, for T2, T3 and T7 there were no differences even in increasing doses of solution presenting average $\mathrm{TCA}_{\mathrm{DC}}$ of $0,047 \mathrm{~mm} \mathrm{day}^{-1}$, therefore, for this variable, the treatment that promoted the greatest increase was T10, fertigation with $670 \mathrm{~mL}$ of fractionated solution in eight times at five-day intervals, from the phenological stage V4, soon was T5 that caused less gain for this variable in the value of $0.021 \mathrm{mmdia}^{-1}$, with a percentage reduction of $89.90 \%$ in relation to $\mathrm{T} 10$.

For $\mathrm{TCR}_{\mathrm{DC}}$ the treatments applied by fertirrigation favored gain for this variable, especially when the corn was cultivated in soil fertilized with T10 and T11 both treatments applied by fertirrigation, whereas the treatments that presented reduction in the increment of this variable were T5 and T2. The highest increases for this variable were reached when the crop was fertilized via fertirrigation, where possibly the availability of nutrients, in a diluted and ready to be absorbed and assimilated by the crop favored this gain, unlike the fertilization of the foundation in which the nutrients were applied to the soil in its entirety following the recommendation of Novais et al. (1991).

With respect to $\mathrm{TCA}_{\mathrm{NF}}, \mathrm{TCR}_{\mathrm{AP}}$ and $\mathrm{TCR}_{\mathrm{NF}}$, fertirrigation treatments formed the ones that promoted the highest gains for these variables, respectively, whereby chemical fertilization via NPK by means of fertilization or applied by fertigation did not promote the highest gains in relation to organic fertilization with treated human urine and cassava wastewater. For $\mathrm{TCA}_{\mathrm{NF}}$ the highest gains were promoted by fertilization with $\mathrm{T} 10, \mathrm{~T} 12, \mathrm{~T} 13$ and T14 (fertilization via fertigation) and T7 (fertilization via the foundation), thus presenting a mean percentage difference of $59.85 \%$ in relation to $\mathrm{T} 2$ that promoted a gain of 0.040 . 
The $\mathrm{TCR}_{\mathrm{AP}}$ as well as for $\mathrm{TCA}_{\mathrm{NF}}$ showed the highest increases when corn was cultivated in soil fertilized with T10 (F 670) and T12 (F1070) with values of 0.045 and $0.047 \mathrm{~cm} \mathrm{plant}^{-1}$, respectively, through which there was a percentage difference of $31.91 \%$ of T12 in relation to T1 (fertilization of foundation with NPK). The $\mathrm{TCR}_{\mathrm{NF}}$ also had significant statistical differences, however with little statistical variability among the treatments, for this variable, T14 was the one that presented the largest increment for the relative growth rate of the number of leaves, so for most of the other treatments there were no differences statistically significant, thus presenting an average rate of 0.714 with an optimum coefficient of variation of $0.46 \%$. Working with the incorporation of cassava wastewater treated in the soil, Ribas et al. (2010) stated that the agronomic characteristics of the corn evaluated (plant height, stem diameter and fresh mass) were not negatively affected by the use of the residue.

In a study conducted by Akpan-Idiok et al. (2012) the use of treated human urine promoted increase in the growth and production of biomass and other crops and compared to plants grown under no fertilization or even with chemical fertilization, corroborating the present study as urine is a free source of nitrogen.

For all the absolute or relative growth rates of the evaluated variables the organic fertilization via fertigation was the one that promoted the greatest growth increments. What could have provided this effect was the fact that the nutrient applications were carried out in a fractional and continuous way throughout the development of the culture of the vegetative stages V4 to the Vn, unlike the fertilization of foundation that received all the nutrients at once in the soil following the recommendation of Novais et al. (1991).

\section{Conclusion}

It was concluded with this study that for the Emergency speed index (IVE) they varied according to the doses of solution (treated human urine plus cassava wastewater), as well as depending on the form of fertilization of the soil in which the corn was cultivated;

Fertilization with chemical fertilization promoted the highest leaf area increments at 15 days after emergence, however, at 65 DAE the highest increments were observed when the soil was fertilized with $670 \mathrm{~mL}$ and 1270 $\mathrm{mL}$ of solution via fertilization foundation and fertirrigado with NPK;

The organic fertilization via fertigation promoted the highest gains for absolute and relative growth rates of plant height $\left(\mathrm{TCA}_{\mathrm{AP}}\right.$ and $\left.\mathrm{TCR}_{\mathrm{AP}}\right)$, stem diameter $\left(\mathrm{TCA}_{\mathrm{DC}}\right.$ and $\left.\mathrm{TCR}_{\mathrm{DC}}\right)$, number of leaves $\left(\mathrm{TCA}_{\mathrm{NF}}\right.$ and $\left.\mathrm{TCR}_{\mathrm{NF}}\right)$.

\section{References}

Akpan-Idioka, A. U., Udob, I. A., \& Braide, E. I. (2012). The use of human urine as an organic fertilizer in the production of okra (Abelmoschus esculentus) in South Eastern Nigeria. Resources, Conservation and Recycling, 62, 14-20. https://doi.org/10.1016/j.resconrec.2012.02.003

ANA (Agência Nacional das Águas). (2002). Evolução dos recursos hídricos no Brasil: Regiões hidrográficas do Brasil, caracterização geral e aspectos prioritários, relatório de gestão 2001 (p. 72). Brasília, Brazil.

APHA (American Public Health Association), AWWA (American Water Works Association), \& WEF (Water Environment Federation). (2005). Standard Methods for the examination of water and wastewater (21st ed.). Washington DC: APHA.

Barreto, M. T. L., Magalhães, A. G., Rolim, M. M., Pedrosa, E. M. R., Duarte, A. S., \& Tavares, U. E. (2014). Desenvolvimento e acúmulo de macronutrientes em plantas de milho biofertilizadas com manipueira. Revista Brasileira de Engenharia Agricola e Ambiental, 18, 487-494. https://doi.org/10.1590/S1415-43662 014000500004

Basi, S., Neumann, M., Marafon, F., Ueno, R. K., \& Sandini, I. E. (2011). Influência da adubação nitrogenada sobre a qualidade da silagem de milho. Revista Brasileira de Tecnologia Aplicada nas Ciências Agrárias, 4, 219-234. https://doi.org/10.5777/PAeT.V4.N3.13

Benincasa, M. M. P. (2003). Análise de crescimento de plantas, noções básicas (2nd ed., p. 41). Jaboticabal, FUNEP.

Bernardo, S., Mantovani, E. C., \& Soares, A. A. (2008). Manual de Irrigação (p. 611). Viçosa, UFV.

Cereda, M. P. (2003). Tecnologia, usos e potencialidades de tuberosos amilácias. In M. P. Cereda, \& O. F. Vilpoux (Eds.), Processamento da mandioca como mecanismo de detoxificação (p. 47-81). São Paulo: Fundação Cargill.

Dantas, M. S. M., Rolim, M. M., Duarte, A. de S., Pedrosa, E. M. R., Tabosa, J. N., \& Dantas, D. da C. (2015). Crescimento do girassol adubado com resíduo líquido do processamento de mandioca. Revista Brasileira de 
Engenharia Agrícola e Ambiental, 19, 350-357. https://doi.org/10.1590/1807-1929/agriambi.v19n4 p350-357

Do Nascimento, E. M. G. C. (2013). Benefícios e perigos do aproveitamento da casca de maracujá (Passiflora edulis) como ingrediente na produção de alimentos. Revista do Instituto Adolfo Lutz, 72(3), 1-11. https://doi.org/10.18241/0073-98552013721536

Duarte, A. P., Kiehl, J. C., Camargo, M. A. F., \& Reco, P. C. (2003). Acúmulo de matéria seca e nutrientes em cultivares de milho originárias de clima tropical e introduzidas de clima temperado. Revista Brasileira de Milho e Sorgo, Sete Lagoas, 2(3), 1-19. https://doi.org/10.18512/1980-6477/rbms.v2n3p1-20

Duarte, A. S., Silva, E. F. F., Rolim, M. M., Ferreira, R. F. A. L., Malheiros, S. M. M., \& Albuquerque, F. S. (2012). Uso de diferentes doses de manipueira na cultura da alface em substituição à adubação mineral. Revista Brasileira de Engenharia Agrícola e Ambiental, 16, 262-267. https://doi.org/10.1590/S1415-436620 12000300005

Embrapa (Empresa Brasileira de Pesquisas Agropecuárias). (2006). Centro Nacional de Pesquisa de Solos. Sistema Brasileiro de Classificação de Solos (2nd ed., p. 412). Brasília, DF: Embrapa Produção de Informação. Rio de Janeiro, RJ: Embrapa Solos.

Embrapa Milho e Sorgo. (2012). Introdução e importância econômica do milho. Retrieved from http://www.sistemasdeproducao.cnptia.embrapa.br

Ferreira, D. F. (2011). Sisvar: A computer statistical analysis system. Ciência e Agrotecnologia, Lavras, 35(6), 1039-1042. https://doi.org/10.1590/S1413-70542011000600001

Ferreira, P. V. (2000). Estatística experimental aplicada à agronomia (3rd ed., p. 604). Maceió: UFAL.

Fittschen, I., \& Hahn, H. H. (1998). Characterization of the Municipal Mastewater Parameters Human Urine and Preliminary Comparison with Liquid Cattle Excretion. Water science technology, Alemanha, 38(6), 9-16.

Francis, C. A., Rutger, J. N., \& Palmer, A. F. E. (1969). A rapid method for plant leaf area estimation in maize (Zea mays L.). Crop Science, Ontario, 9, 537-539. https://doi.org/10.2135/cropsci1969.0011183X0009000 $50005 x$

Ganrot, Z., Dave, G., \& Nilsson, E. (2007). Recovery of N and P from human urine by freezing, struvite precipitation and adsorption to zeolite and active carbon. Bioresour Technol, 98, 3112-21. https://doi.org/ 10.1016/j.biortech.2006.10.038

Karak, T., \& Bhattacharyya, P. (2011). Human Urine as a Source of Alternative Natural Fertilizer in Agriculture: A flight of fancy or an achievable reality. Resources, Conservation and Recycling, 55, 400-408. https://doi.org/10.1016/j.resconrec.2010.12.008

Kraemer, M. E. P. (2017). A questão ambiental e os residuos industriais. Retrieved from http://www.amda.org. br/imgs/up/Artigo_25.pdf

Marques, D. M. S., Monteiro Rolim, M. A. R. I. O., Pedrosa, R., Maria, E., da Silva, M. M., \& da Costa Dantas, D. A. N. I. E. L. (2017). Growth and seed yield of sunflower on soil fertilized with cassava wastewater. Revista Caatinga, 30(4), 963-970. https://doi.org/10.1590/1983-21252017v30n417rc

Novais, R. F., Neves, J. C. L., \& Barros, N. F. (1991). Ensaio em ambiente controlado. In A. J. Oliveira (Ed.), Métodos de pesquisa em fertilidade do solo (pp. 189-253). Brasília: Embrapa-SEA.

Picarelli, G. A. (2012). Logistics characterization of the corn of main producing regions of Rio Grande do Sul State. Universidade de São Paulo “Escola Superior de Agricultura Luiz de Queiroz”, Piracicaba, SP.

Ribas, M. M. F., Cereda, M. P., \& Villas Boas, R. L. (2010). Use of cassava wastewater treated anaerobically with alkaline agents as fertilizer for maize (Zea mays L.). Brazilian Archives of Biology and Technology, 53, 55-62. https://doi.org/10.1590/S1516-89132010000100007

\section{Copyrights}

Copyright for this article is retained by the author(s), with first publication rights granted to the journal.

This is an open-access article distributed under the terms and conditions of the Creative Commons Attribution license (http://creativecommons.org/licenses/by/4.0/). 